\title{
Il disegno della città nelle tavole del De Nola. Metodi della rappresentazione e della tipografia
}

\author{
Pasquale Argenziano
}

Abstract

II testo è incentrato sull'analisi grafica di due delle quattro tavole pubblicate nel libro De Nola di Ambrogio Leone, sviluppata anche a confronto con le evidenze topografiche della città contemporanea. Questi disegni sono particolarmente interessanti per l'intrinseco valore documentario sia in relazione alla città antica e a quella rinascimentale, sia in relazione alle tecniche grafiche a stampa, allora innovative e in fase di primo sviluppo.

In particolare, nelle pagine seguenti vengono approfonditi gli aspetti relativi ai metodi della rappresentazione e alle tecniche tipografiche, basandosi sulla scienza del Disegno della tavola intitolata Nola Vetus, la seconda del trattato.

Questo contributo è in continuità con quelli di Alessandra Avella e Nicola Pisacane pubblicati in questo libro e con i precedenti presentati al Convegno UID 2020, e cerca di consolidare la definizione del poliedrico carattere di Ambrogio Leone, che fu disegnatore, topografo e tipografo, oltreché noto erudito umanista.

\section{Parole chiave}

documentazione, geometria, cartografia, Gutenberg, UNESCO.

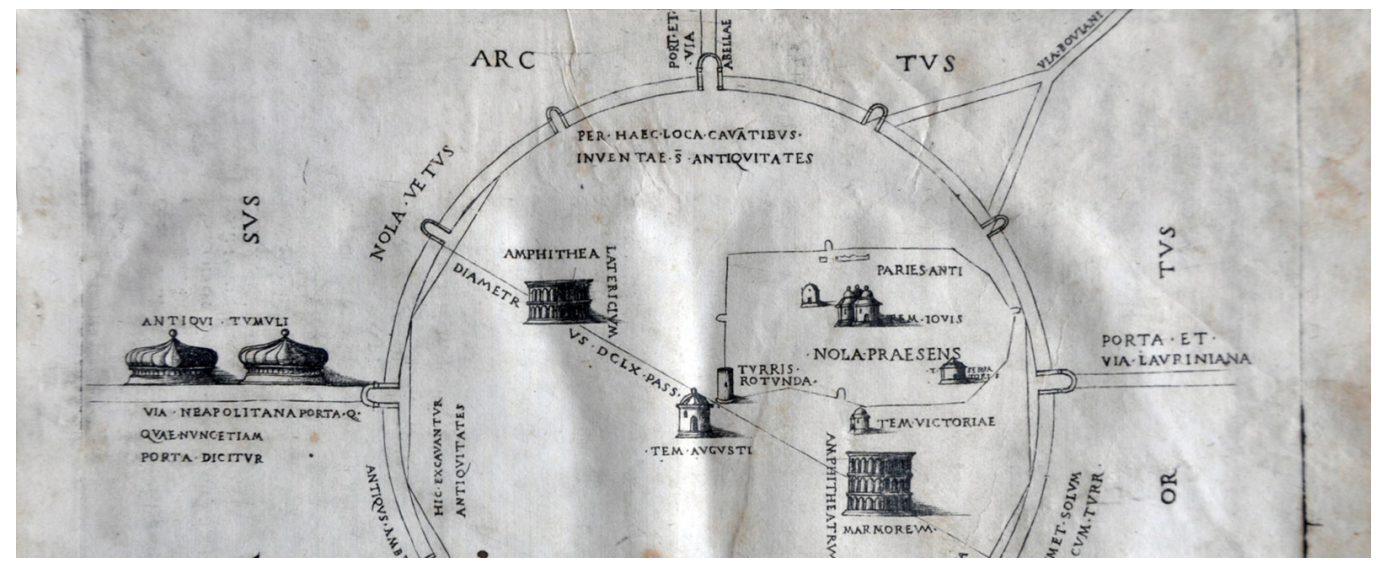




\section{Introduzione}

II Trattato De Nola (I5|4) [I] di Ambrogio Leone [2] è corredato da quattro tavole, tre delle quali già esaminate in precedenti pubblicazioni. Questo paper prosegue [3] e integra [4] quegli studi con l'analisi geometrica e grafica della Tavola II intitolata Nola Vetus.

Le quattro tavole sono un importante documento grafico di Nola nella sua fase rinascimentale e di riflesso nella sua fase classica, supportate da articolare descrizioni nel testo suddiviso in tre libri. Nel primo libro, l'autore descrive il territorio nolano e la città a partire dall'epoca classica con riferimento alla Tavola I Ager Nolanus e alla Tavola II Nola Vetus. Nel secondo libro, Leone descrive la città rinascimentale con approfondimenti sugli elementi difensivi, sugli edifici nobiliari, religiosi e civili con riferimento alla Tavola III Figura praesentis urbis Nolae e alla Tavola IV Nola Presens; nel terzo libro, infine, descrive gli usi e i costumi dei suoi concittadini dedicando ampio spazio alla tradizione della Festa dei Gigli [5].

La Festa dei Gigli è in realtà lo spunto investigativo da cui è partita la lettura critica delle quattro tavole perché essa è una parte di una più ampia ricerca condotta nell'ambito del progetto finanziato dalla Regione Campania per lo studio, la salvaguardia e la valorizzazione degli elementi culturali dell'autenticità dei Gigli di Nola, della sua festa e della sua comunità, iscritti nella lista del Patrimonio Immateriale UNESCO [6].

Questo studio specifico della tavola Nola Vetus (fig. I) - collegata ai testi dei capitoliVII eVIII del primo libro - è condotto a partire dai risultati dell'analisi geometrica e algebrica della tavola Figura praesentis urbis Nolae, l'unica delle quattro tavole supportata da una accurata descrizione testuale anche con precisi riferimenti al perimetro e all'estensione di Nola, a

Fig. I. Tavola II (Nola Vetus): ortorettifica e scala in once napoletane $\mathrm{e}$ in millimetri.

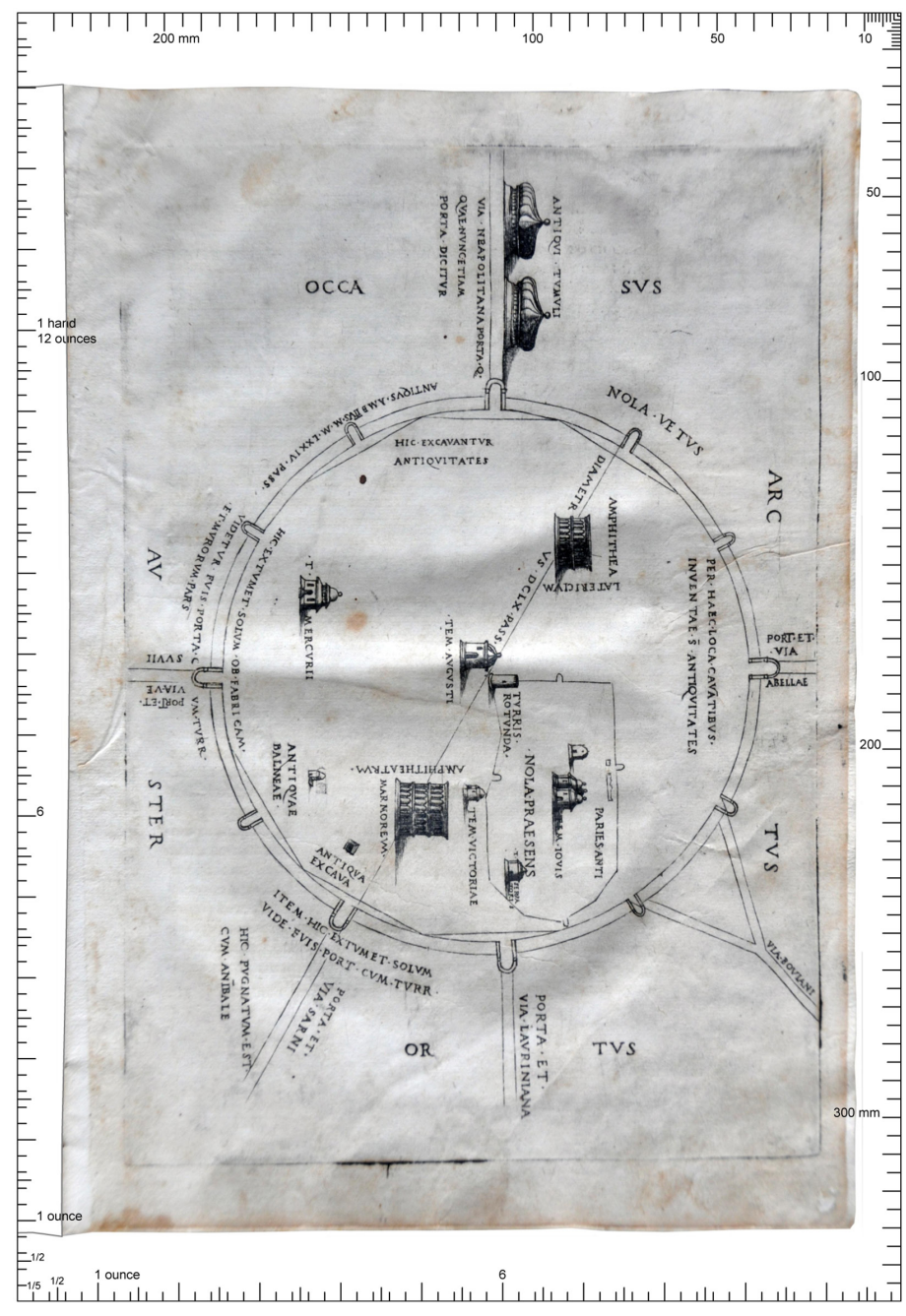


confronto tra l'età romana e quella rinascimentale. Secondo l'approccio metodologico proprio della disciplina del Disegno [7] già adottato per l'analisi delle Tavole I, III e IV, le analisi della Tavola II sono di carattere geometrico-dimensionale, relative ai metodi della rappresentazione, alle caratteristiche tipografiche e alle caratteristiche geografiche comparate alla cartografia contemporanea. In particolare, nel presente studio sono descritte e illustrate le analisi sui metodi della rappresentazione adottati dal disegnatore e sulle caratteristiche tipografiche della Tavola Nola Vetus a confronto con la Tavola Figura praesentis urbis Nolae.

\section{L'uso iconico delle proiezioni parallele e il progetto tipografico della Tavola Nola Vetus}

La Tavola Nola Vetus descrive la città antica in riferimento al contesto territoriale di appartenenza; il suo perimetro murario circolare con indicazione dimensionale del diametro (unica quota nella tavola); le principali emergenze architettoniche - religiose, civili e difensive - integrando alcune rinascimentali con quelle classiche visibili al suo tempo; e il periodo storico di appartenenza attraverso sintetici testi che narrano avvenimenti utili a collocarla storicamente. II Leone disegna nella Tavola II e descrive nel capitolo VIII del Trattato solo quelle evidenze materiali che lo confortano nel sostenere l'ipotesi di una forma circolare della città antica di Nola, singolare nel panorama delle città del periodo romano. È da segnalare che la circonferenza, identificata con il centro e il diametro, è il riferimento analitico di questo testo e dei saggi di Avella e Pisacane pubblicati in questo volume, ai quali si rinvia per una lettura completa dello studio condotto sul tema.

L'inquadramento territoriale della città è descritto attraverso i testi che definiscono la posizione geografica del perimetro urbano in riferimento alle principali emergenze corografiche del territorio circostante. L'idrografia e l'orografia del territorio, infatti, non sono disegnate, così come mancano le località urbane indicate nella tavola, la rete viaria a eccezione di quella che dalle porte della cinta difensiva conduce verso le diverse emergenze corografiche indicate.

Nello specifico, nella direzione est-ovest della tavola lungo il diametro orizzontale del cerchio, all'estremità occidentale è disegnata la via Neapolitana Porta che conduce verso Napoli. L'ipotesi dell'appartenenza di questa via alla città antica di Nola è sostenuta dallo stesso Leone nel capitolo descrittivo della Tavola, nel quale sottolinea che a quel luogo è associata storicamente la denominazione "porta", come testimoniano la presenza nelle sue vicinanze della cappella di S. Pietro presso la porta e lungo il suo tragitto e precisamente di fronte alla cappella, antichissime tombe nella Tavola denominate "Antiqui tumuli" [8]. Queste tombe sono descritte e disegnate da Leone come strutture ampie a pianta circolare che si restringono all'apice, terminando a forma di cono con al centro una punta. All'estremità opposta del diametro orizzontale del cerchio, a oriente è disegnata una via ampia, lunga e rettilinea, denominata via Lauriniana, che a partire dall'omonima porta antica della città conduce verso la località di Laurinium.

Nella direzione nord-sud della tavola, lungo il diametro verticale del cerchio, a partire dalle porte della cinta muraria ed esternamente al perimetro urbano, è disegnata una via retta che all'estremità settentrionale è denominata via Abellae e che dall'omonima porta conduce verso la località e i monti di Abella, mentre all'estremità opposta è denominata via Vesuvii che dall'omonima porta conduce verso il monte Vesuvio. Lungo la diagonale del cerchio all'estremità nord-est è disegnata la via retta denominata via Boviani che a partire dalla biforcazione viaria - che ha origine dall'intersezione di due vie di uguale dimensione provenienti da due porte successive della cinta urbana - conduce verso la località di Bovianum. Analogamente, lungo la diagonale del cerchio all'estremità sud-est, simmetricamente a quella nord-est rispetto all'orizzontale Neapolitana Porta - via Lauretana, è disegnata la via Sarni che dall'omonima porta conduce verso la località urbana di Sarnum.

Per quanto riguarda la struttura circolare della città antica il Leone ne definisce la forma anche grazie ad alcuni resti delle fondamenta del muro di cinta ancora riconoscibili sul territorio al suo tempo. Nel disegno il centro del cerchio coincide con la base della Turris Rotunda verso il quadrante ovest; si ricorda che la Turris collocata nel vertice sud-ovest della cinta fortificata della città Rinascimentale è l'elemento architettonico che ricorre in tutte le Tavole 
a eccezione della Tavola III. Questo elemento è l'unico della Nola coeva a Leone, insieme al perimetro della cinta fortificata, a essere disegnato nella Tavola II.

La rappresentazione della cinta fortificata della Nola rinascimentale sembra essere una riduzione di scala e una conseguente semplificazione grafica di quella disegnata nella Tavola III del De Nola, unica documentazione della struttura difensiva aragonese della città.

Le principali emergenze architettoniche, religiose, civili e difensive disegnate nella Tavola sono i due anfiteatri, le tombe e i templi per la maggior parte riconoscibili al tempo di Leone attraverso i loro ruderi, le loro fondamenta o frammenti di pavimenti come nel caso dei templi.

Gli anfiteatri sono quello laterizio e quello marmoreo [9] allineati lungo la diagonale del cerchio. I templi disegnati nella Tavola e descritti nel Trattato sono: il Tempio della Vittoria (Tem Victoriae) a settentrione dell'anfiteatro marmoreo; il Tempio di Giove (Tem lovis) ancora più a settentrione di quello della Vittoria; il Tempio del Salvatore procedendo verso oriente a partire da questi; il Tempio di Augusto (Tem Augusti) tra i due anfiteatri, e il Tempio di Mercurio (T. Mercurii) a sud. Completano la Tavola alcuni sintetici testi che in alcuni casi indicano la posizione di reperti e relative aree di rinvenimento, in altri descrivono avvenimenti storici che il Leone scrive essere accaduti in quei luoghi.

Le tavole del Trattato - a esclusione della Tavola III che ha un carattere prevalentemente geometrico - hanno un omogeneo impiego di differenti metodi di rappresentazione privilegiando una rappresentazione accidentale con un punto di vista in posizione elevata [Manzi 1973]. Nello specifico la Tavola II appare come un'icnografia del tracciato murario della città romana lungo il quale la proiezione verticale delle dodici porte urbiche è rappresentata ribaltata nella direzione perpendicolare ai raggi. Le architetture rappresentate prevalentemente in proiezione verticale ortogonale appaiono iconiche delle rispettive tipologie piuttosto che allusive di una verosimiglianza con la realtà. I due anfiteatri sembrano fare eccezione o meglio la loro rispettiva rappresentazione iconica trova riscontro con la descrizione di Leone. L'autore, infatti, sostiene che l'anfiteatro in laterizio doveva essere più basso di quello in marmo di un ordine di archi, valutando le caratteristiche di ciò che dell'impianto originario è ancora visibile ai suoi tempi.

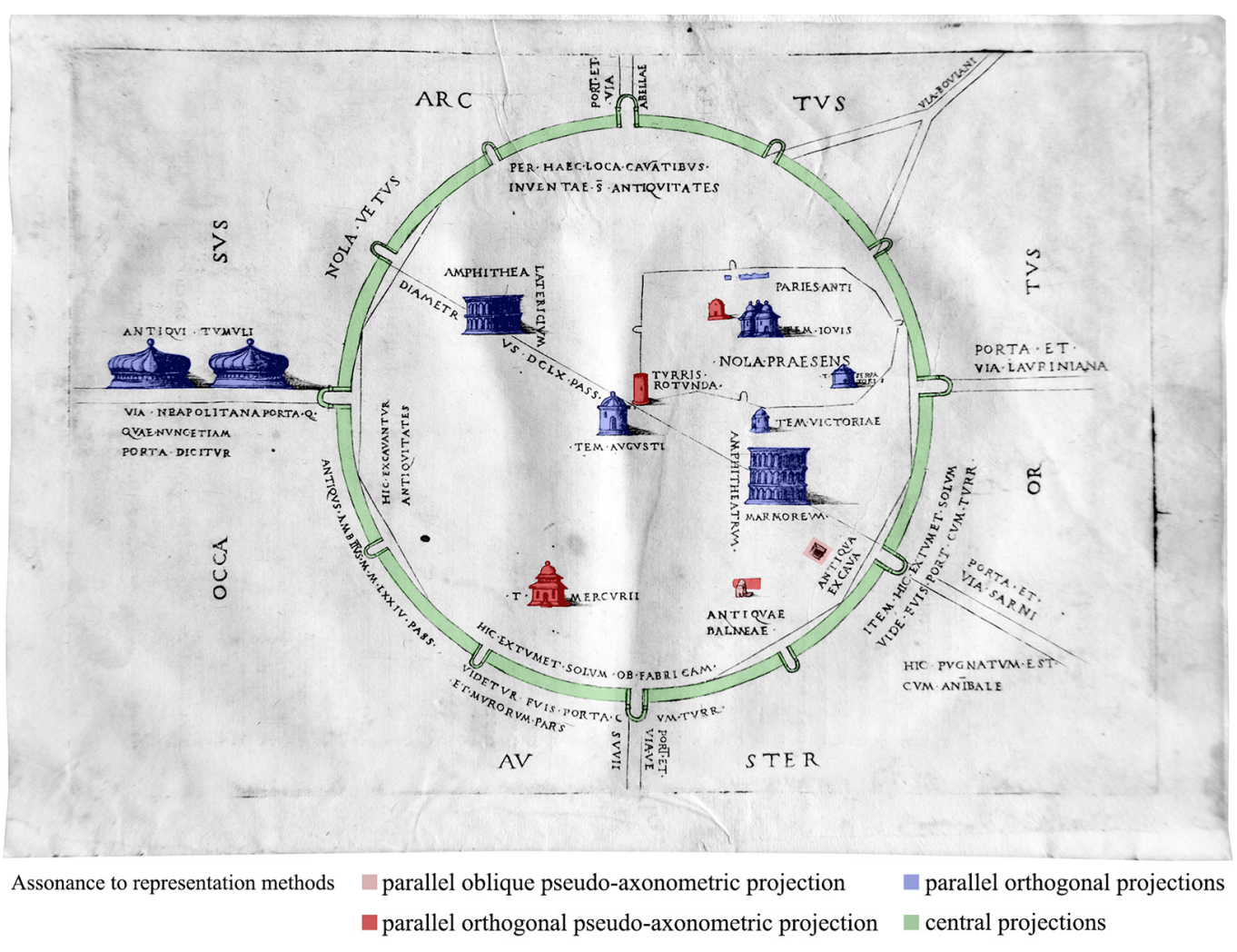


L'analisi è stata condotta classificando le architetture e le opere difensive rappresentate secondo l'assonanza formale ai metodi di rappresentazione (proiezioni parallele e centrali) a ulteriore conferma di un punto di vista dinamico (figg. 2 e 6). La rappresentazione in proiezione centrale della cinta difensiva della città e delle porte è di certo singolare. Se si osserva la relazione tra le due strade che si raccordano a Y (in alto a destra) e le rispettive porte urbiche si può notare che il disegnatore applica l'espediente grafico già noto e solo di recente definito come "completamento amodale". Le due strade convergenti a partire dalle rispettive porte urbiche sono in parte nascoste dalle mura così da alludere alla relazione tridimensionale tra il perimetro circolare e i nastri stradali. Analogamente devono perciò essere interpretate le strade che si irradiano dalle altre porte urbiche.

L'effetto spaziale della rappresentazione è enfatizzato dal chiaroscuro applicato alle icone architettoniche in modo omogeneo. La scena sembra essere illuminata da una fonte luminosa posta nel quadrante sud-ovest (Auster - Occasus), analogamente alliconografia della Tavola IV Nola Presens.
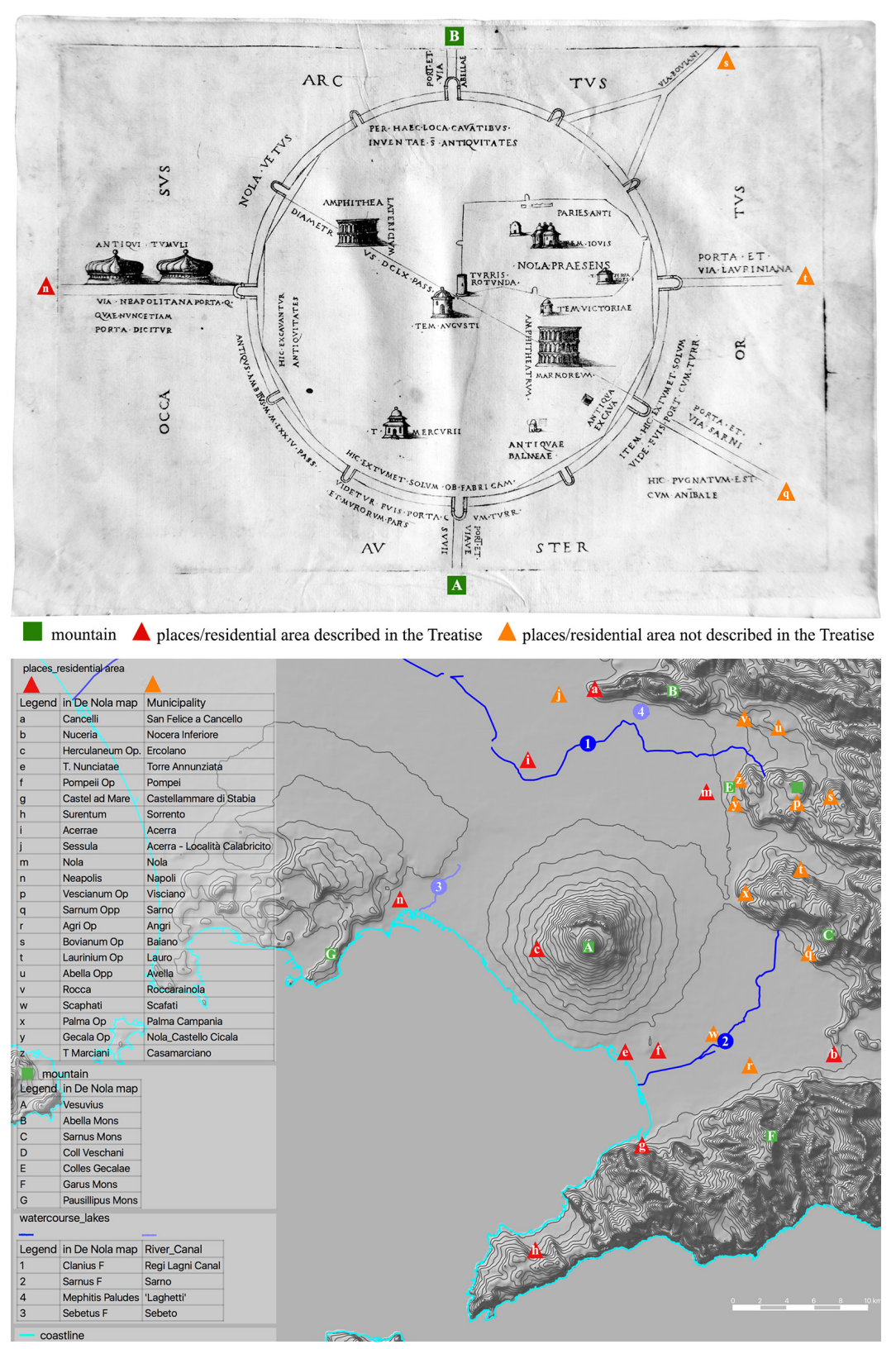
Gli elementi di confronto tra i luoghi rappresentati dal Leone nella Tavola II e la realtà attuale sono stati primo elemento di discussione nella figura 3 ex7 che evidenzia nella Tavola Nola Vetus le località raggiungibili attraverso le direttrici di collegamento che dipartono dal perimetro circolare della città romana. A partire da alcune delle dodici porte urbiche sono disegnati sei assi stradali che, in una lettura in senso orario della stessa Tavola partendo da nord, conducono rispettivamente alle località ora rintracciabili in Avella, Baiano, Lauro, Sarno, monte Vesuvio e Napoli. Queste località, presenti anche tra quelle indicate nella Tavola Ager Nolanus [I 0], sono state individuate attraverso il Progetto GIS della ricerca nella attuale topografia dei luoghi evidenziando il corretto orientamento degli stessi nella Tavola II rispetto alla città di Nola e tra loro. Ciò testimonia oltre alla profonda conoscenza dei luoghi da parte del Leone, anche la sua capacità nel corretto disegno del territorio.

Le figure 4 e 5 analizzano le caratteristiche tipografiche della Tavola II in relazione ai testi in essa presenti e citati nel De Nola. Tutte le Tavole del Trattato sono corredate da testi didascalici in caratteri capitali di dimensione variabile in relazione alla tipologia di informazione a eccezione della Tavola III nella quale il sistema di quotatura alfanumerico è in corsivo. La figura 4 ex 8 tematizza i testi in funzione delle informazioni a esse associate; la figura 5 ex 9 , invece, in relazione alla direzione dei testi e alle relative altezze.

Nello specifico, la tematizzazione dei testi riguarda la posizione geografica della città antica di Nola, la denominazione delle principali porte urbane con indicazione dell'orientamento in riferimento alla corografia del territorio, i dati dimensionali della struttura circolare urbana (misura della circonferenza e del diametro del cerchio), le emergenze architettoniche religiose, civili e difensive, i reperti e le relative aree di rinvenimento, le architetture della città rinascimentale, i sintetici testi che narrano secondo quanto scritto da Leone avvenimenti utili a collocarla storicamente e il titolo della Tavola.

Per quanto riguarda l'allineamento dei testi sono individuate quattro diverse direzioni: orizzontale, verticale, circolare e radiale. In particolare, in quest'ultima tipologia ricadono la denominazione delle antiche porte urbane e delle principali vie di collegamento della città con il territorio circostante e la dimensione espressa nell'unità di misura in passi del diametro

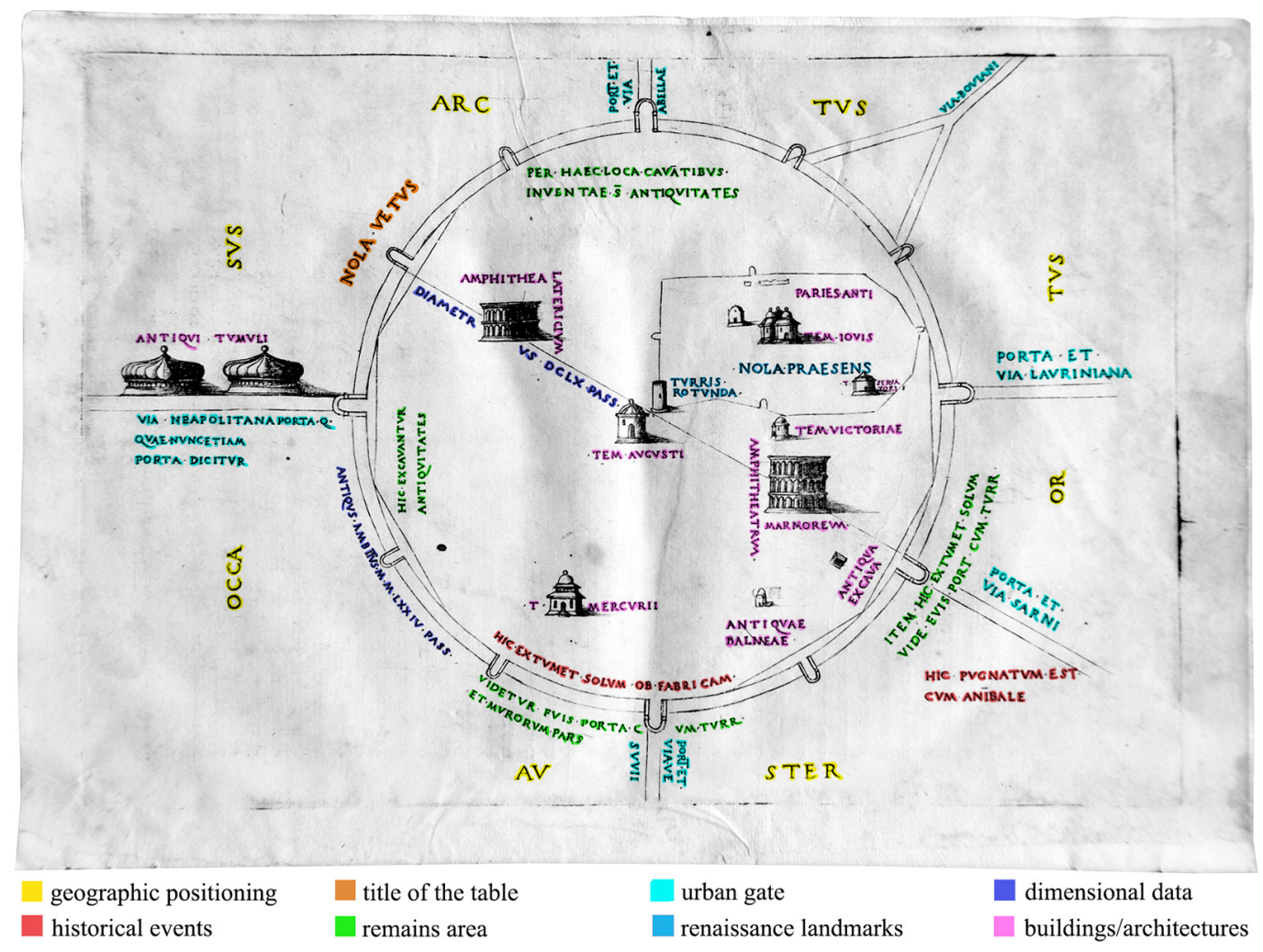


della struttura circolare urbana. La direzione circolare dei testi, invece, riguarda la descrizione degli avvenimenti storici e l'indicazione delle aree di ritrovamento dei reperti. I testi relativi all'orientamento cardinale, invece, sono paralleli ai quattro bordi dei fogli e hanno direzione verso l'alto e verso sinistra secondo la convenzione oggi in uso. Tutti gli altri testi della tavola hanno direzione verticale e orientamento verso sinistra a eccezione dei testi che si riferiscono ai due anfiteatri per i quali si evidenziano delle difformità rispetto alle regole di allineamento che sottendono l'intera Tavola. In particolare, la scritta Amphithea riferita all'anfiteatro laterizio è allineata orizzontalmente e collocata sopra al disegno dell'anfiteatro, mentre l'analoga scritta Amphitheatrum riferita all'anfiteatro marmoreo corre verticalmente lungo l'altezza dell'edificio e, diversamente dalle altre scritte che hanno direzione verticale, è orientata a destra; analogamente, la scritta Latericium è allineata verticalmente lungo l'altezza dell'anfiteatro ed è orientata verso destra, mentre la scritta Marmoreum è allineata orizzontalmente e collocata al di sotto del disegno dell'anfiteatro.

Due sono le altezze dei testi utilizzati dal disegnatore, come già anticipato: $i$ testi cardinali sono un minuto di oncia (1/5), gli altri sono in media di un decimo di oncia. Queste valutazioni dimensionali hanno portato ad acquisire un ulteriore dato sulla composizione grafica della tavola. I testi curvilinei secondo la curvatura della cinta muraria sono posizionati su una serie concentrica di righi equidistanti un minuto di oncia e occupanti una corona larga un'oncia. II nastro della cinta muraria occupa un modulo di questa corona.

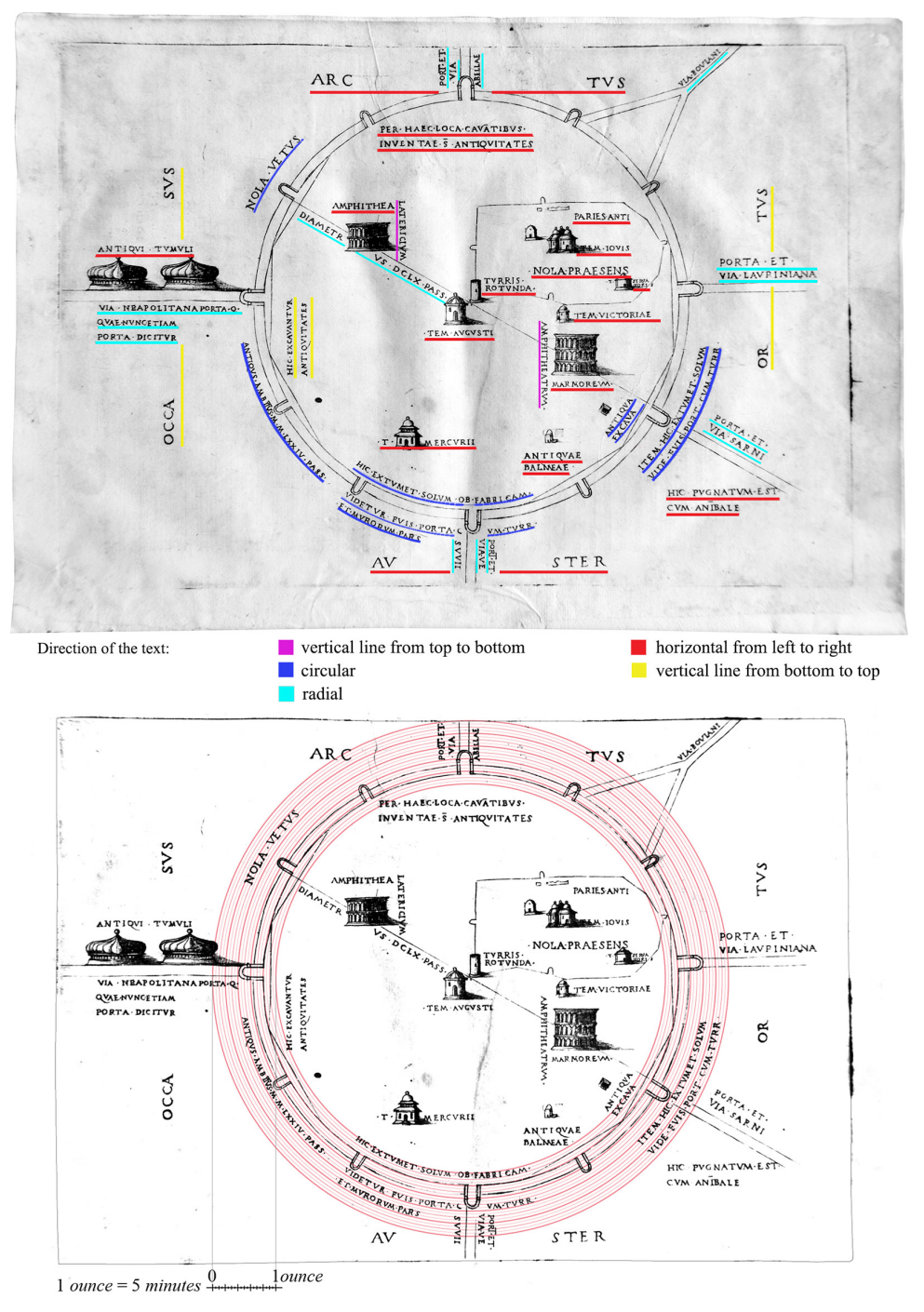




\section{Conclusioni}

Le analisi qui condotte attraverso la sistematizzazione dei dati desunti dalle Tavole del De Nola [I I ] nel progetto GIS hanno evidenziato alcune valutazioni critiche nel presente testo e nei contributi pubblicati in questo volume [12], e altre che potranno essere ulteriormente ampliate nel campo archeologico e topografico. Nel primo si potrà far riferimento alla localizzazione cartografica di tutte le campagne di scavo archeologico condotte sul territorio così come dei dati descrittivi desumibili da documenti e dalla bibliografia di settore sul tema, nel secondo ai metodi, alle tecniche e quindi agli strumenti di rilevamento in uso al tempo. La sintesi di tutte le informazioni raccolte ed elaborate nell'ambito della più ampia ricerca condotta potrà essere di ulteriore supporto all'analisi delle Tavole del Leone che disvelano una personalità poliedrica di disegnatore, topografo e tipografo oltre quelle note di erudito umanista [13].

\section{Note}

[I] L'analisi dei quattro disegni è condotta su uno degli esemplari della prima edizione a stampa conservati nella Biblioteca Nazionale di Napoli, la cui collocazione è SQ.LVI.D. I6. Successivamente alla prima edizione curata da Leone e verosimilmente da Mocetto, il De Nola vanta sei edizioni latine in volumi miscellanei o monografici e due traduzioni in italiano (1934; 1997).

[2] Ambrogio Leone (Nola I 458 ca - Venezia 1525) è una singolare figura della cultura italiana rinascimentale, di collegamento tra gli ambienti degli eruditi napoletani, quelli veneziani e quelli d'oltralpe che frequentavano le rispettive capitali (Spruit 2005).

[3] Si veda: Argenziano, Avella, Pisacane 2021, pp. 883-894; Avella, Pisacane, Argenziano 2020, pp. I598- I62 I; Pisacane, Argenziano, Avella A. (in corso di stampa).

[4] II presente contributo è parte integrante della ricerca in corso sulle iconografie del Trattato De Nola a cura di Pasquale Argenziano, Alessandra Avella e Nicola Pisacane; e in particolare la sua lettura è completata dai saggi Avella A., /I disegno della città nelle tavole del De Nola. Analisi geometrico-dimensionale delle iconografie, e Pisacane N., Il disegno della città nelle tavole del De Nola. Analisi degli aspetti geografici e cartografici, pubblicati in questo volume di Atti.

[5] Leone I5।4, bks. III, 7.

[6] I Gigli di Nola rientrano nella Rete delle grandi macchine a spalla italiane, iscritta dal 2013 nella Lista del Patrimonio Culturale Immateriale dell'UNESCO, unitamente alla Nostra Signora della Santa Lettera di Palmi, alla Discesa dei Candelieri di Sassari e alla Macchina di Santa Rosa di Viterbo.

[7]Vagnetti 1973; Pagnano 2003; Zerlenga 2004.

[8] I ruderi sono oggi visibili in via Polveriera [Leone 1997, p. 178, nota 5].

[9] La distruzione dell'anfiteatro marmoreo, completata ai tempi di Leone, è a opera di Orso Orsini, valoroso guerriero e grande mecenate della città di Nola, che trasse le pietre dall'anfiteatro nolano per restaurare e ampliare la sua Reggia. II toponimo Castelrotto con il quale si identificano i resti dell'anfiteatro marmoreo, è fatto risalire da Leone alla presenza al centro dell'anfiteatro di una fabbrica all'apparenza simile a un castello che sorgeva ai suoi tempi su un rialzamento del suolo dovuto all'accumulo dei resti dell'anfiteatro originario [Ruggero 1997, p. 176, nota 4].

[I0] Pisacane, Argenziano, Avella (in corso di stampa).

[I I]Vedi nota 3.

[12]Vedi nota 4.

[13] Le immagini a corredo del testo, ad eccezione di quelle di repertorio, sono a cura di Alessandra Avella, Pasquale Argenziano, Nicola Pisacane.

\section{Riferimenti bibliografici}

Argenziano P., Avella A., Pisacane N. (2021). Geometry and Urban Shape of the City of Nola through the Drawings of the De Nola by A. Leone (I5I4). In L-Y. Cheng (a cura di). 19th ICGG 2020. Proceedings of the $19^{\text {th }}$ International Conference on Geometry and Graphics, Advances in Intelligent Systems and Computing, vol. I296, pp. 883-894. Switzerland: Springer.

Avella A., Pisacane N., Argenziano P. (2020). The drawing of the Renaissance city from De Nola's tables to contemporary cartographical data. In A. Arena et al. (a cura di). Connettere. Un disegno per annodare e tessere. Atti del $42^{\circ}$ Convegno Internazionale UID, pp. I598-I62 I. Milano: FrancoAngeli.

Campone M.C. (2015). Figura praesentis urbis Nolae: geometric theorems and classical sources in Renaissance's urbanism and in De Nola by Ambrogio Leone. In C. Gambardella (a cura di). Heritage and Technology. Mind Knowledge Experience, Atti del XIII Forum Internazionale di Studi "Le Vie dei Mercanti". Aversa-Capri, I I- 3 June 20 I5, pp. I855- I 864. Napoli: La Scuola di Pitagora editrice. 
Carillo S. (1996). Alcune osservazioni sulla pianta della città allegata al De Nola di Ambrogio Leone. In T. R. Toscano (a cura di). Nola e il suo territorio dalla fine del Medio Evo al XVII secolo. Momenti di storia culturale e artistica, pp. 25-44. Castellammare di Stabia: Ager Nolanus.

De Seta C., Buccaro A. (a cura di). (2006). Iconografia delle città in Campania. Napoli e i centri della provincia. Napoli: Electa Napoli.

Leone A. ( I | 4). De Nola. Opusculum distinctum, plenum, clarum, doctum, pulchrum, verum, grave, varium, et utile. Venezia: Giovanni Rosso.

Leone A. (1934). Nola (la terra natia).Traduttore Paolino Barbati. Napoli:Tipografia Torella.

Leone A. ( 1997). Nola.Traduttore Andrea Ruggiero. Napoli: Istituto Grafico Editoriale Italiano.

Manzi. P. (1973). Alcuni documenti di cartografia nolana ovvero: Ambrogio Leone e Gerolamo Moceto. In L'Universo, vol. LIII, n. 4 , pp. $811-818$.

Pagnano G. (2003). Presentazione. In G. Pagnano (a cura di). Ikhnos. Analisi grafica e storia della rappresentazione, vol. I, pp. 7- I0. Siracusa: Lombardi Editori.

Pisacane N., Argenziano P., Avella A. (in corso di stampa). The Ager Nolanus Table by Ambrogio Leone and Girolamo Mocetto as prototype of modern cartography.

Sampaolo, V. ( 1996). Nola. In Enciclopedia dell'Arte Antica Treccani, vol. V. p. 537. <https://www.treccani.it/enciclopedia/nola res-488d774b-66c0-I l el-b49|-d5ce3506d72e_\%28Enciclopedia-dell\%27-Arte-Antica\%29/> (consultato il 28 aprile 202 I).

Spruit L. (2005). Leone, Ambrogio. In Dizionario Biografico degli Italiani. Treccani, vol. 64, <https://www.treccani.it/enciclopedia/ ambrogio-leone_(Dizionario-Biografico)> (consultato il 28 aprile 202I).

Vagnetti L. (1973). L'architetto nella storia di Occidente. Firenze:Teorema.

Visconti F. (1838). Del sistema metrico della città di Napoli e della uniformità de' pesi e delle misure che meglio si conviene a' reali domini di qua dal faro. Napoli: Stamperia Reale.

Zerlenga O. (2004). II disegno della città. Napoli rappresentata in Pianta eVeduta. In G. Pagnano (a cura di). Ikhnos. Analisi grafica e storia della rappresentazione, vol. II, pp. I I-34. Siracusa: Lombardi Editori.

Autore

Pasquale Argenziano, Università della Campania “Luigi Vanvitelli”, pasquale.argenziano@unicampania.it

Per citare questo capitolo: Argenziano Pasquale (2021). II disegno della città nelle tavole del De Nola. Metodi della rappresentazione e della tipografia/City drawing In De Nola's Tables. The representation methods and typographic analysis In Arena A.,Arena M., Mediati D., Raffa P. (a cura di). Connettere. Un disegno per annodare e tessere. Linguaggi Distanze Tecnologie. Atti del $42^{\circ}$ Convegno Internazionale dei Docenti delle Discipline della Rappresentazione/Connecting. Drawing for weaving relationship. Languages Distances Technologies. Proceedings of the $42^{\text {th }}$ International Conference of Representation Disciplines Teachers. Milano: FrancoAngeli, pp. 85-102. 


\title{
City Drawing in De Nola's Tables. The Representation Methods and Typographic Analysis
}

\author{
Pasquale Argenziano
}

\section{Abstract}

The text focuses on the graphic analysis of two of the four tables published in De Nola Treatise ( $15 \mid 4$ ) by Ambrogio Leone, also developed in comparison with the topographic evidence of the contemporary city. These drawings are particularly interesting for their intrinsic documentary value both in relation to the ancient city and the Renaissance one, and in relation to the printing techniques, then innovative and in the first development phase.

The following pages examine in detail the table entitled Nola Vetus, the second of the treatise, about the aspects relating to methods of representation and typographic techniques, based on the science of Drawing.

This paper is in continuity with those of Alessandra Avella and Nicola Pisacane published in this book and with the previous ones presented at the UID 2020 Conference, and seeks to consolidate the definition of the multifaceted character of Ambrogio Leone, who was a draftsman, topographer and printer, as well as a well-known humanist scholar.

Keywords

documentation, geometry, maps, Gutenberg, UNESCO.

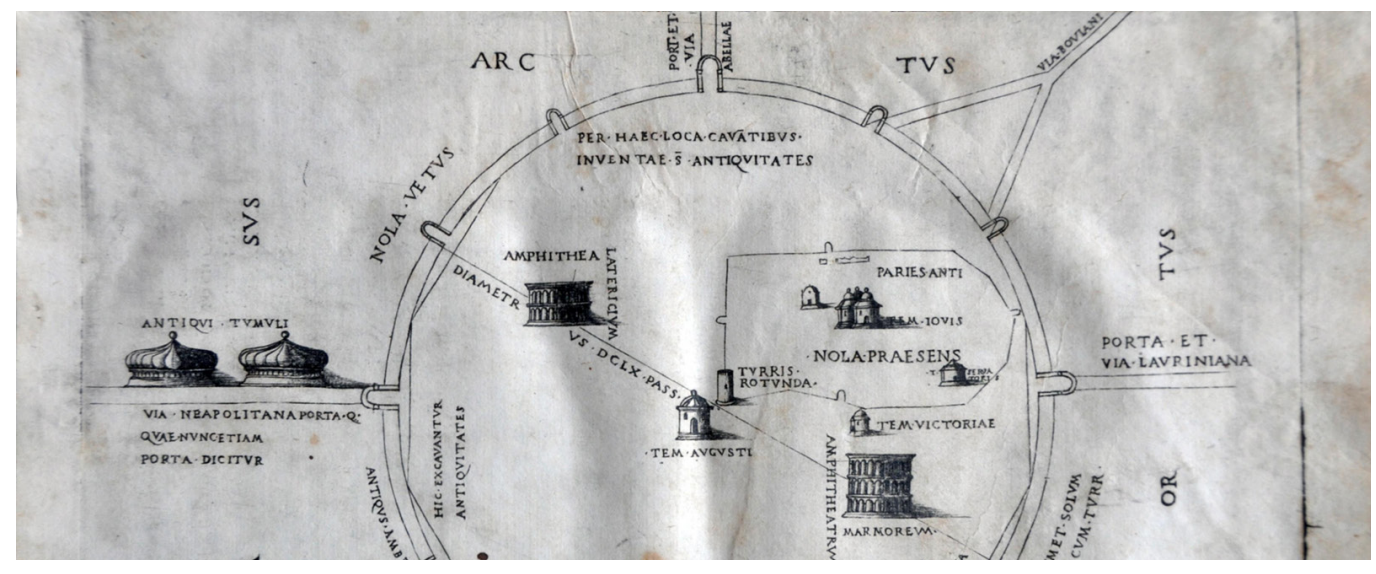




\section{Introduction}

The treatise De Nola ( 15 I 4 [ I] by Ambrogio Leone [2] is integrated by four tables, three of which were analysed in previous papers. This paper follows [3] and accomplishes [4] those studies with the geometrical analysis of Table II, titled Nola Vetus.

The treatise's drawings are an important graphic-documentary testimony of the Renaissance Nola described by Leone in the three books in which he organizes his work. In the first book the author describes the Nola territory according to a chronological reading and with a wide dissertation on the classical city, according to Table I, titled Ager Nolanus, and Table II, titled Nola Vetus. In the second book, Leone describes ows contemporary city and its structure with in-depth analysis about the defensive elements, the aristocratic, religious and civil buildings, according to Table III, titled Figura praesentis urbis Nolae, and Table IV titled Nola Presens. Finally, the author describes the uses and traditions of his fellow citizens, including the tradition of Festa dei Gigli [5] celebration.

The Festa dei Gigli is actually the investigative starting point of analysis of the four tables because the celebration is part of a wider research developed within the Research Project funded by Regione Campania aimed at the study for the safeguard and enhancement of the cultural elements of the Gigli di Nola obelisks registered on the UNESCO Intangible Heritage List [6].

This paper focused on Nola Vetus Table (fig. I) -referred to the its description in chapters VII and VIII of the first book- is carried out starting from the results already obtained following the geometric and algebraic analysis of Figura praesentis urbis Nolae Table, the only one of

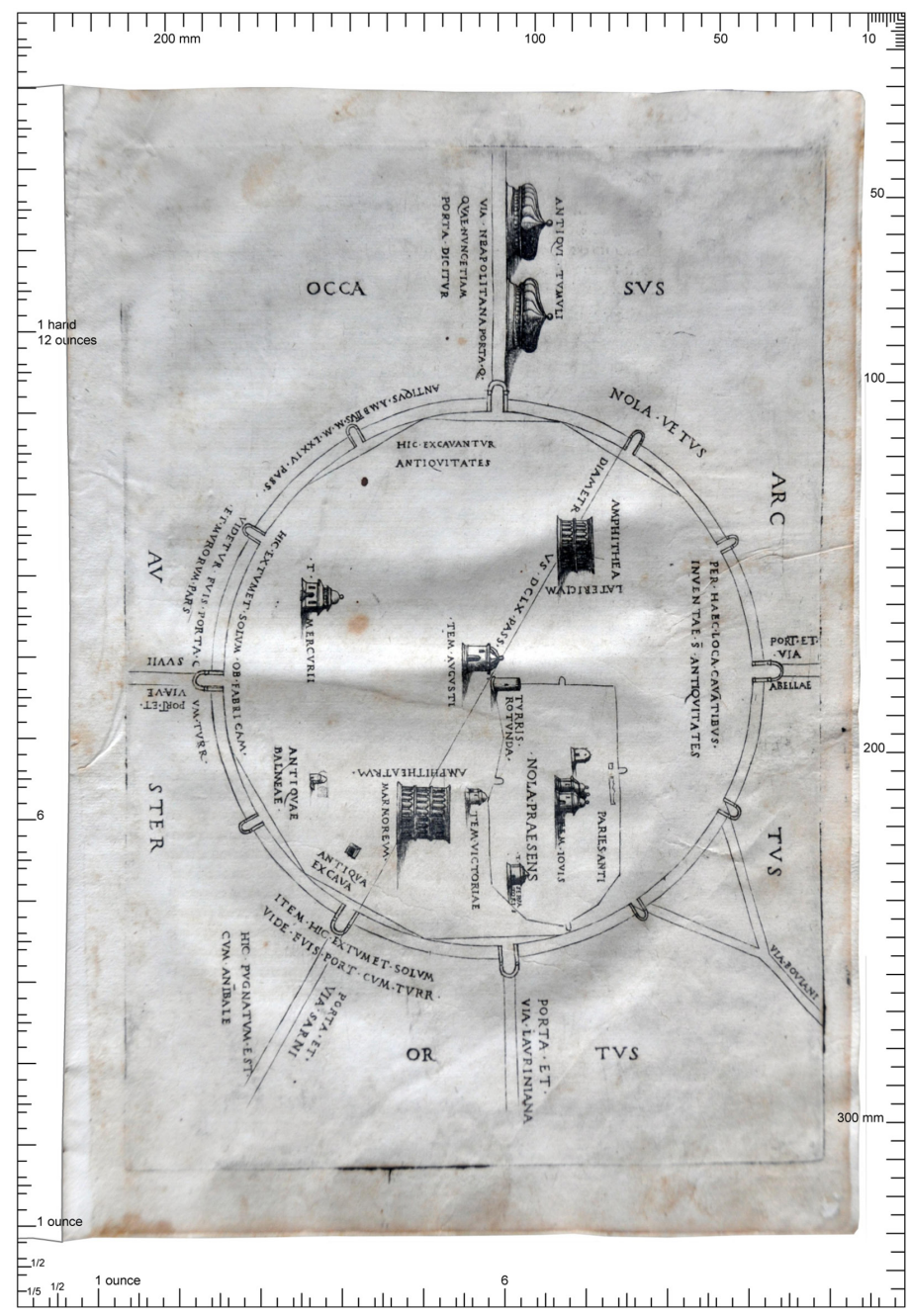


the four Tables in which the author makes an accurate description of the drawing also with precise references both to the perimeter and to the extension of the city of Nola, both in Roman times and in the Renaissance period.

According to the methodological approach of the Discipline of Drawing [7]- already adopted for the analysis of Tables I, III and IV- the analyses of Table II are about the dimensional and geometrical aspects, the methods of representation, the typographical characteristics and geographical ones compared to contemporary cartography. In particular, this paper describes and illustrates the analyses on the methods of representation adopted by the draftsman, and on the typographical characteristics of Nola Vetus Table, compared with the Figura praesentis urbis Nolae Table.

\section{An iconic use of parallel projections, and the typographical design of Table AA of Nola Vetus Table}

The Table II describes: the ancient city in its territorial context; the circular wall perimeter highlighted with the diameter dimension line which is the only graphical reference in the Table; the main ancient buildings visible in the Sixteenth century (religious, civil and defensive) integrated with some Renaissance ones; and the historical timing of the iconography, through synthetic texts that narrate ancient events. Leone draws in Table II and describes in chapter VIII of the Treatise only those material evidence that comforts him to support the hypothesis of the circular shape of the ancient city of Nola, which is singular in the panorama of the cities of the Roman period.

It should be noted that the circumference -identified with the centre and diameter- is the reference of all the analyses of this paper, and of the essays of Avella and Pisacane published in this proceeding book; the full reading of this study is possible in conjunction with those two papers.

The territorial framework of the city is described through some textual annotations that define the geographical location of the urban perimeter referred to the main chorographic elements of the surrounding territory. The hydrography and orography, as the urban locations are not drawn; even, the urban road network is not drawn except for the external urban wall one that leads from the gates to the different chorographic elements.

Specifically, along the Est-West direction on the Table, the Via Neapolitana Porta leading towards Naples is drawn along the horizontal diameter of the city, at the western end. The hypothesis of the belonging of this street to the ancient city of Nola is supported by Leone in the descriptive chapter of the Table; he points out that the name 'gate' is historically associated with that place, as two elements can confirm. The first one is the chapel of S. Pietro presso la porta; the second one, is the location of two ancient tombs, called Antiqui tumuli [8] along that route and in front of the chapel. These tombs are described and drawn by Leone as large circular structures, which narrow at the apex, ending with a cone. At the Eastern end of the horizontal diameter of the urban circle, opposite the previous one, a wide, long and straight road is drawn, called Via Lauriniana; this leads to the town of Laurinium from the homonym ancient gate.

In the North-South direction of the Table, along the vertical diameter of the urban circle, starting from the gates and outside them, a straight road is drawn and is called Via Abellae, evidently it leads to the town and mountains of Abella; while at the opposite end of the city, there is the Via Vesuvii that leads to Mount Vesuvius starting from the gate of the same name. Along the diagonal of the urban circle, at the North-East end, the straight road called Via Boviani is drawn; it leads to the town of Bovianum starting from the road junction that begins at the intersection of two roads coming from as many adjacent urban gates. Similarly, at the South-East end, the Via Sarni is drawn; it leads to the town of Sarnum from the homonym gate.

As for the circular perimeter of the ancient city, Leone defines its shape also thanks to some remains of the wall foundations still recognisable on the territory, during his time. In the drawing, the centre of the circle coincides with the base of the Turris Rotunda towards the 
West quadrant; it should be remembered that the Turris is the architectural element that recurs in all Tables, except Table III, and it is placed in the South-West summit of the Renaissance fortified city. This tower and the fortified perimeter are the only elements of the city of Nola coeval to Leone drawn in Table II.

The representation of the I5th-century fortified wall seems to be a scale reduction and a consequent graphic simplification of that drawn in Table III, which is the only documentation of the Aragon defensive elements. The main buildings (religious, civil and defensive) drawn in the Table are the two Amphitheatres, tombs and temples probably recognisable and described by Leone at his time, thanks to their ruins, their foundations or fragments of the floors, as in the case of temples.

The Amphitheatres, one in brick and the other in marble [9], are aligned along the diagonal of the circle.The temples drawn in the Table and described in the Treatise are:Temple of Victory (Tem Victoriae) located to the North of the marble Amphitheatre; Temple of Jupiter (Tem lovis) located even further North than the previous one; Salvatore Temple located in the East, compared to the previous ones; Temple of Augustus (Tem Augusti) located between the Amphitheatres and the Temple of Mercury (T.Mercurii), in the South. Some synthetic textual notes that indicate the location of finds and their discovery areas complete the Table, or they describe historical events that Leone claims to have happened in those specific places.

The Tables of the Treatise - with the exception of Table III because it has a predominantly geometric character- have a homogeneous use of different methods of representation, favouring an accidental representation with a point of view in a high position [Manzi 1973]. Specifically, Table II appears as an ichnography of the urban wall path of the ancient city along which the vertical projection of the 12 urban gates is represented tipped in the direction perpendicular to the rays. The buildings represented mainly in vertical orthogonal projection appear iconic of each type, rather than allusive of real likelihood. The two amphitheatres seem to be the exception, however, or rather each iconic representation is matched by the textual description of Leone. The author, in fact, argues that the brick Amphitheatre should have been lower than the marble Amphitheatre of an order of arches, being able to evaluate these characteristics by the ruins, still visible in Renaissance time.

Fig. 2. Table II, classification of religious buildings, civil and defense according to formal assonance to the
methods of representation.

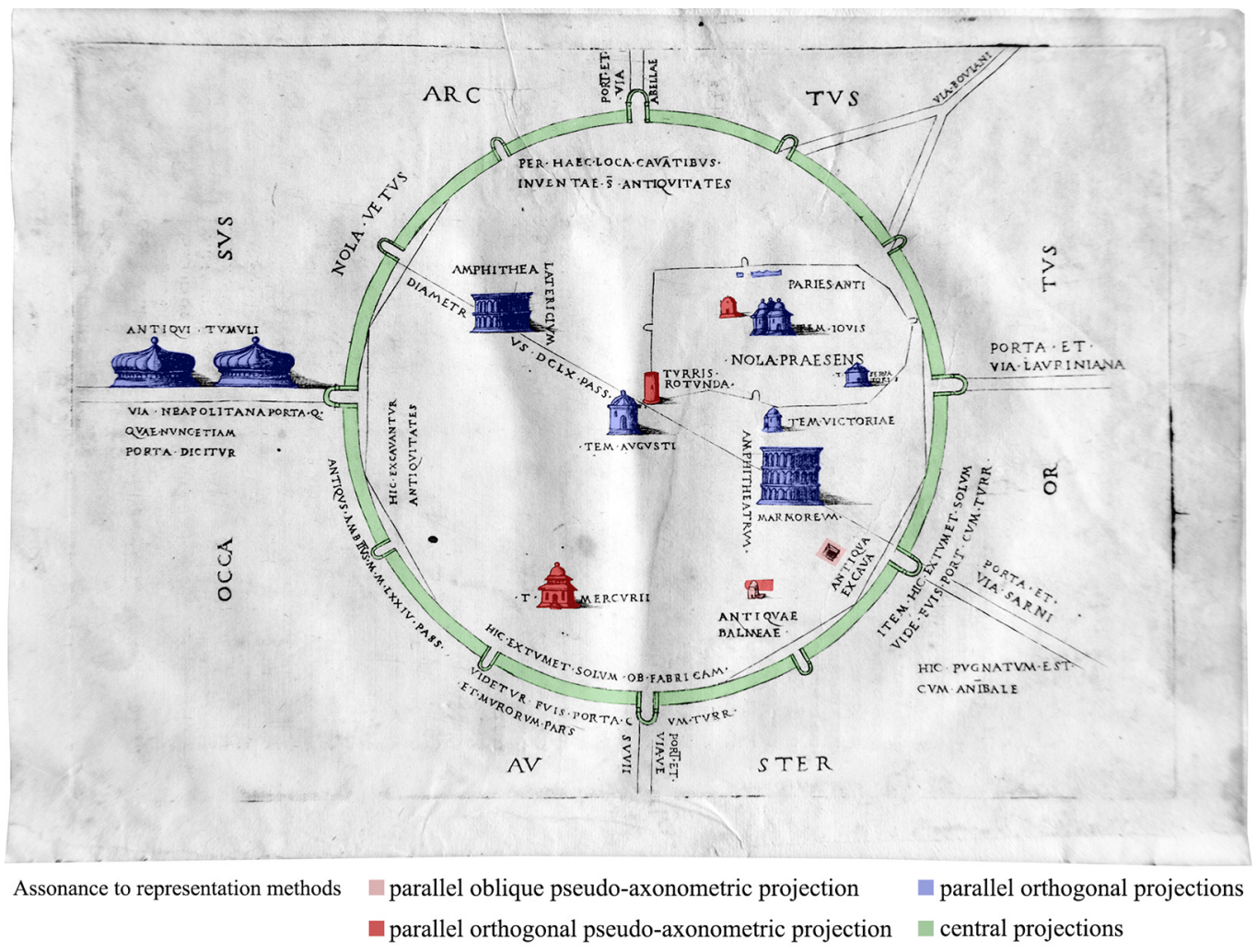


The analysis was carried out by classifying the buildings and defensive ones represented according to the formal assonance to the methods of representation (parallel and central projections) as further confirmation of a dynamic point of view (fig. 2). The central projection representation of the city's defensive wall and gates is certainly singular. Looking at the relationship among the roads connecting to $Y$ (top right) and their urban gates, it can see that the draftsman applies the well-known graphical gimmick, recently called "amodal completion". The converging roads starting from the respective urban gates are partly hidden by the walls so as to allude to the three-dimensional relationship between the circular perimeter and the road tapes. The same must therefore be interpreted as the roads radiating from the other urban gates.

The spatial effect of the representation is emphasised by chiaroscuro applied to buildings icons in a homogeneous way. The scene appears to be illuminated by a light source in the South-West quadrant (Auster - Occasus), similar to the iconography of Table IV, titled Nola Presens.
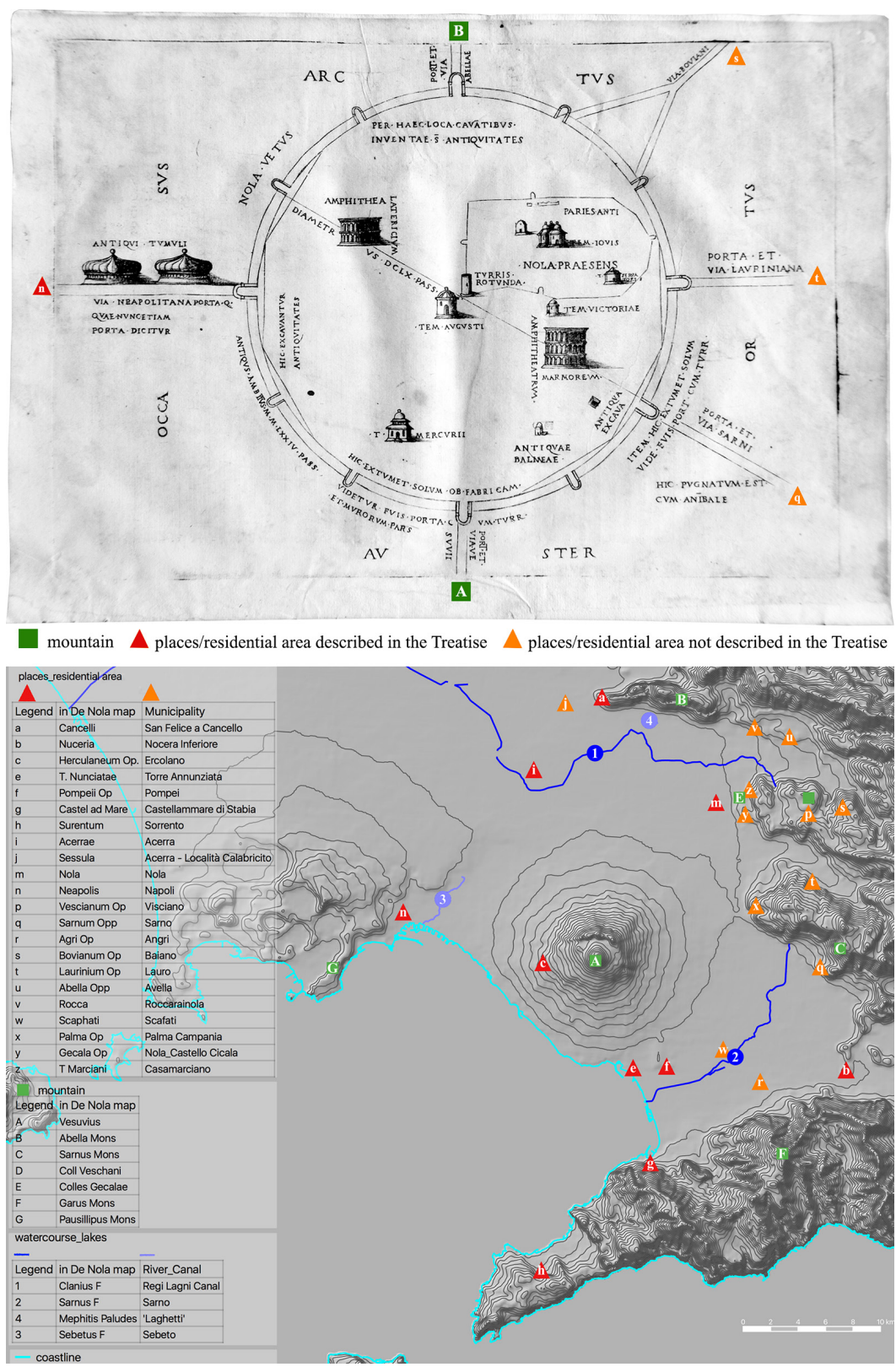
Comparison elements between the places represented by Leone in Table II and the nowadays reality were the first element of discussion in figure 3 Nola Vetus Table highlights the locations reachable through the connecting roads that depart from the circular perimeter of the ancient city. Starting from some of the twelve urban gates are drawn six roads that, in a clockwise reading starting from North, lead respectively to the contemporary locations of Avella, Baiano, Lauro, Sarno, Vesuvius and Naples. These locations, also present among those indicated in Ager Nolanus Table [10], have been identified through the GIS project in the current positions highlighting the correct orientation of the same in Table II with reference to the city of Nola and among them. This testifies not only to the deep knowledge of the places by Leone, but also to his ability in land drawing.

Figures 4 and 5 analyse the typographical characteristics of Table II in relation to the texts in it and mentioned in De Nola Treatise. All Tables of the Treatise are accompanied by caption in capital letters of varying size in relation to the type of information with the exception of Table III in which dimensions are in italic. Figure 4 thematizes the texts according to the information associated with them; figure 5 , on the other hand, in relation to the direction of the texts and their heights.

Specifically, the theme of the texts concerns the geographical location of the ancient city of Nola, the naming of the main urban gates with their orientation according to land chorography, the dimension of the urban circular structure (length of the circumference and diameter of the circle), religious, civil and defensive buildings, finds and discovery areas, the architecture of the Renaissance city, the synthetic texts that narrate, according to Leone's writing, events useful to place it historically and the title of the Table.

Concerning the texts alignment, four different directions are identified: horizontal, vertical, circular and radial. In particular, the latter typology includes the name of the ancient urban gates and the main connecting routes of the city with the surrounding territory and the size of the diameter of the urban circular structure expressed in steps. The circular direction of the texts, on the other hand, concerns the description of historical events and the indication of the discovery areas of the finds. The texts relating to the cardinal orientation,

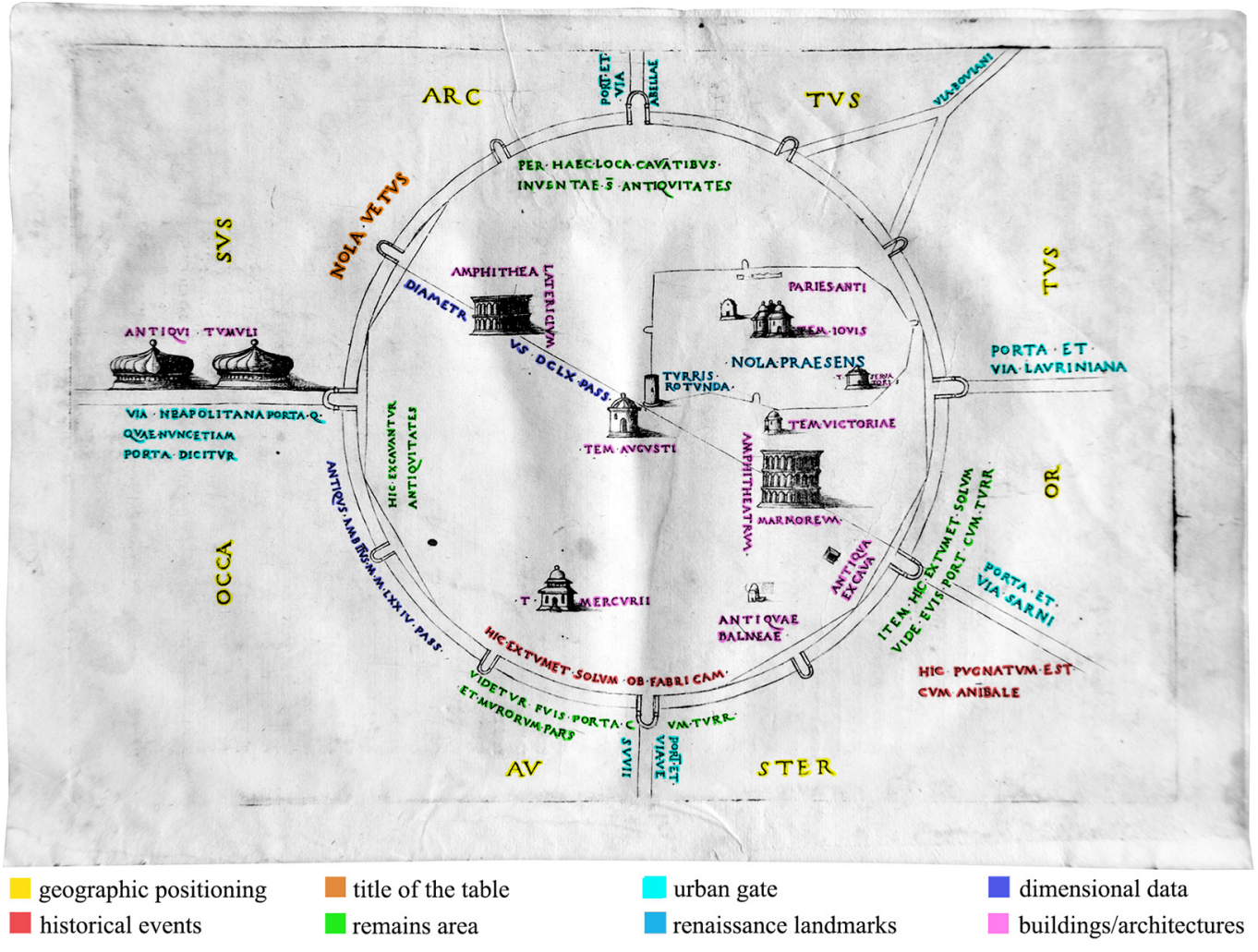


on the other hand, are parallel to the four edges of the sheets and have upward and left direction according to the convention currently in use. All the other texts of the table have a vertical direction and a leftward orientation to the meaning of the texts referring to the two Amphitheaters for which there are differences with respect to the alignment rules that underlie the entire Table. In particular, the inscription Amphithea referring to the brick Amphitheater is aligned horizontally and placed above the drawing of the Amphitheater, while the analogous inscription Amphitheatrum referring to the marble Amphitheater runs vertically along the height of the building and, unlike the other writings that have a vertical direction, is oriented to the right; similarly, the text Latericium is vertically aligned along the height of the Amphitheater and is oriented to the right, while the inscription Marmoreum is aligned horizontally and placed below the drawing of the Amphitheater.

There are two heights of the texts used by the draftsman, as already mentioned: the cardinal texts are one minute of ounce $(1 / 5)$, the others are on average one tenth of an ounce. These dimensional evaluations have led to a further data on the graphic composition of the Table. Curvilinear texts according to the curvature of the walls are placed on a concentric series of circles equidistant each other I minute of I ounce and occupying a crown I ounce wide. The ribbon of the urban walls occupies a module of this crown.

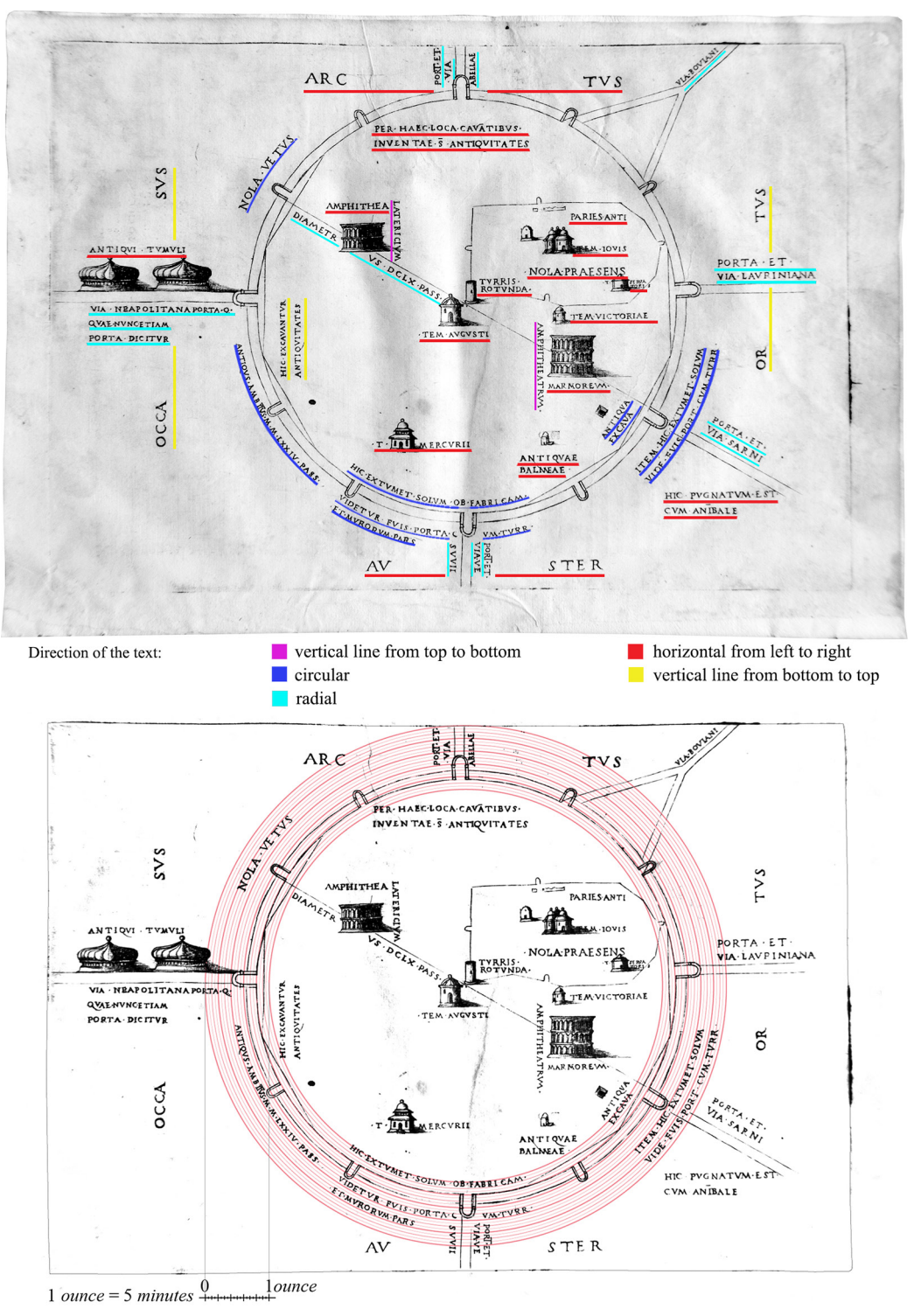




\section{Conclusions}

The analyses carried out in the paper through the systematization of the data taken from De Nola [I I] Tables in the GIS project have highlighted some critical evaluations in this paper and other one in this proceeding book [12], and further ones can be expanded in the archaeological and topographic field. In the first it will be possible to refer to the cartographic localization of all archaeological excavation campaigns conducted in the territory as well as descriptive data inferred from documents and bibliography on the subject, in the second to the methods, techniques and therefore to the detection tools in use at the time. The synthesis of the information, collected and elaborated in the widest research, may be of further support to the analysis of Leone's Tables; in fact, they reveal a multifaceted personality of draftsman, topographer, and typographer beyond those already known as humanist scholar [I3].

\section{Notes}

[I] The analysis of the four drawings is conducted on a copy of the first printed edition stored in the National Library in Naples; its shelfmark is SQ.LVI.D. I6. After the first edition (15/4) edited by Leone and probably by Mocetto, De Nola had six Latin editions in miscellaneous or monographic books, and two Italian translations (1934; 1997).

[2] Ambrogio Leone (Nola I458 ca - Venice I525) is a singular person of Italian Renaissance culture, connecting the environments of the Neapolitan scholars, the Venetian ones and those from beyond the Alps who frequented their respective capitals (Spruit, 2005)

[3] See: Argenziano, Avella, Pisacane 2021, pp. 883-894; Avella, Pisacane, Argenziano 2020, pp. I 598- I62 I; Pisacane, Argenziano, Avella (in press).

[4] The paper is part of the ongoing research on the iconography of the De Nola Treatise carried out by the author of this essay with Pasquale Argenziano and Alessandra Avella. In particular, the iconographic analysis is completed by the essays Avella A., City drawing in De Nola's Tables. Geometric-dimensional analysis of the iconographies and Nicola Pisacane, City drawing in De Nola's Tables. Geographical and cartographical analysis features, published in this Proceedings book.

[5] [Leone | $5 \mid 4$, bks. III, 7].

[6] Gigli di Nola obelisks are included, together with the obelisks of Nostra Signora della Santa Lettera of Palmi, Discesa dei Candelieri of Sassari and Macchina di Santa Rosa of Viterbo, in the Network of large Italian shoulder machines, inscribed since 2013 in the UNESCO Intangible Heritage List.

[7] Vagnetti 1973; Pagnano 2003; Zerlenga 2004.

[8] Today, the ruins are visible in Via Polveriera [Leone 1997, p. 178, nota 5].

[9] The destruction of the marble Amphitheater, ended in the time of Leone, is carried out by Orso Orsini -a valiant warrior and great patron of the city of Nola- who took the stones from the Nola Amphitheater to restore and expand his palace.The place name Castelrotto with which the remains of the marble Amphitheater are identified, is traced by Leone to the presence in the center of the Amphitheater of a factory that looks similar to a castle that stood at the time on a rise in the ground due to the accumulation of the remains of the original Amphitheater. (Ruggero 1997, p. 176, nota 4).

[I0] Pisacane, Argenziano, Avella (in press).

[I I] See, n. 3 endnote.

[12] See, n. 4 endnote.

[13] Figures, except for archive images, are edited by Alessandra Avella, Pasquale Argenziano, Nicola Pisacane.

\section{References}

Argenziano P., Avella A., Pisacane N. (2021). Geometry and Urban Shape of the City of Nola through the Drawings of the De Nola by A. Leone (15|4). In L-Y. Cheng (a cura di). 19th ICGG 2020. Proceedings of the 19th International Conference on Geometry and Graphics, Advances in Intelligent Systems and Computing, vol. I296, pp. 883-894. Switzerland: Springer.

Avella A., Pisacane N., Argenziano P. (2020). The drawing of the Renaissance city from De Nola's tables to contemporary cartographical data. In A. Arena et al. (a cura di). Connettere. Un disegno per annodare e tessere. Atti del $42^{\circ}$ Convegno Internazionale UID, pp. I598-1621. Milano: FrancoAngeli.

Campone M.C. (2015). Figura praesentis urbis Nolae: geometric theorems and classical sources in Renaissance's urbanism and in De Nola by Ambrogio Leone. In C. Gambardella (a cura di). Heritage and Technology. Mind Knowledge Experience, Atti del XIII Forum Internazionale di Studi "Le Vie dei Mercanti". Aversa-Capri, I I-I 3 June 20 I 5, pp. I 855- I 864. Napoli: La Scuola di Pitagora editrice. 
Carillo S. (1996). Alcune osservazioni sulla pianta della città allegata al De Nola di Ambrogio Leone. In T. R. Toscano (a cura di). Nola e il suo territorio dalla fine del Medio Evo al XVII secolo. Momenti di storia culturale e artistica, pp. 25-44. Castellammare di Stabia: Ager Nolanus.

De Seta C., Buccaro A. (a cura di). (2006). Iconografia delle città in Campania. Napoli e i centri della provincia. Napoli: Electa Napoli.

Leone A. ( I | 4). De Nola. Opusculum distinctum, plenum, clarum, doctum, pulchrum, verum, grave, varium, et utile. Venezia: Giovanni Rosso.

Leone A. (1934). Nola (la terra natia).Traduttore Paolino Barbati. Napoli:Tipografia Torella.

Leone A. ( 1997). Nola.Traduttore Andrea Ruggiero. Napoli: Istituto Grafico Editoriale Italiano.

Manzi P. (1973). Alcuni documenti di cartografia nolana ovvero: Ambrogio Leone e Gerolamo Moceto. In L'Universo, vol. LIII, n. 4 , pp. $811-818$.

Pagnano G. (2003). Presentazione. In G. Pagnano (a cura di). Ikhnos. Analisi grafica e storia della rappresentazione, vol. I, pp. 7- I0. Siracusa: Lombardi Editori.

Pisacane N., Argenziano P., Avella A. (in corso di stampa). The Ager Nolanus Table by Ambrogio Leone and Girolamo Mocetto as prototype of modern cartography.

Sampaolo V. ( 1996). Nola. In Enciclopedia dell'Arte Antica Treccani, vol. V, p. 537. <https://www.treccani.it/enciclopedia/nola res-488d774b-66c0-I l el-b49|-d5ce3506d72e_\%28Enciclopedia-dell\%27-Arte-Antica\%29/> (accessed 202 I, April 28).

Spruit L. (2005). Leone, Ambrogio. In Dizionario Biografico degli Italiani. Treccani, vol. 64, <https://www.treccani.it/enciclopedia/ ambrogio-leone_(Dizionario-Biografico)> (accessed 2021,April 28).

Vagnetti L. (1973). L'architetto nella storia di Occidente. Firenze:Teorema.

Visconti F. ( 1838). Del sistema metrico della città di Napoli e della uniformità de' pesi e delle misure che meglio si conviene a' reali domini di qua dal faro. Napoli: Stamperia Reale.

Zerlenga O. (2004). II disegno della città. Napoli rappresentata in Pianta eVeduta. In G. Pagnano (a cura di). Ikhnos. Analisi grafica e storia della rappresentazione, vol. II, pp. I I-34. Siracusa: Lombardi Editori.

\footnotetext{
Author

Pasquale Argenziano, Università della Campania “Luigi Vanvitelli”, pasquale.argenziano@unicampania.it
}

To cite this chapter. Argenziano Pasquale (2021). Il disegno della città nelle tavole del De Nola. Metodi della rappresentazione e della tipografia/ City drawing In De Nola's Tables. The representation methods and typographic analysis In Arena A., Arena M., Mediati D., Raffa P. (a cura di). Connettere. Un disegno per annodare e tessere. Linguaggi Distanze Tecnologie. Atti del $42^{\circ}$ Convegno Internazionale dei Docenti delle Discipline della Rappresentazione/Connecting. Drawing for weaving relationship. Languages Distances Technologies. Proceedings of the $42^{\text {th }}$ International Conference of Representation Disciplines Teachers. Milano: FrancoAngeli, pp. 85- 102. 